DOI: $10.5216 / h r . v 15 i 1.10821$

\title{
Letramento e Mediações Culturais em “Pueblos” IndíGENAS do Centro-Sul do MÉXICO NO SÉCULO XIX
}

Gabriela Pellegrino Soares* gabriela.pellegrino@terra.com.br

Resumo: $\mathrm{O}$ artigo busca lançar luz sobre usos das letras herdados e mobilizados pelos pueblos indígenas do centro-sul do México do período pós-independência. Desde a época colonial, a escrita constituía um instrumento importante para que as comunidades indígenas acionassem os tribunais vice-reinais em defesa de terras e direitos. A elaboração das petições jurídicas apoiava-se no trabalho de mediadores letrados, que transcreviam depoimentos orais. Com a independência da Nova Espanha, em 1821, essa tradição se manteve, mas ajustada às estruturas jurídicas do Estado em formação. Ao mesmo tempo, ao longo do século XIX, os pueblos continuaram a lutar pela presença de um professor de primeiras letras capaz de alfabetizar e ensinar o espanhol às novas gerações.

Palavras-Chave: México, século XIX, indígenas, letras, educação.

A historiografia voltada aos redemoinhos que continuaram a arrastar a sociedade mexicana nos anos que se seguiram à Revolução costuma apresentar, como um divisor de águas na história cultural do país, o ambicioso projeto de promoção do maestro rural alentado por José Vasconcelos, primeiro a assumir a Secretaria de Educação Pública (SEP) restaurada, em 1921, por Alvaro Obregón. Decidido a reverter o quadro de analfabetismo e de precário domínio do espanhol que caracterizava boa parte da população nacional, Vasconcelos concebeu diferentes estratégias para espalhar

* Professora de História da América Independente do Departamento de História da Faculdade de Filosofia, Letras e Ciências Humanas da Universidade de São Paulo, Brasil. Uma versão deste texto foi originalmente apresentada no VII Encontro da Associação Nacional de Pesquisadores em História da América Latina e Caribenha (ANPHLAC), ocorrido na Unicamp, em outubro de 2006 e está no prelo da Revista Bibliográfica e Histórica, da PUC de Campinas, SP. Agradeço à Fapesp pelo auxílio financeiro que permitiu a realização, no México, da pesquisa que embasa este artigo. Agradeço também ao Colegio de México por ter acolhido minha proposta de pós-doutoramento. 
professores missionários pelos confins do território, fazendo da instrução elementar a nova prioridade na esfera das políticas educacionais.

Pouco a pouco, a primeira leva de maestros misioneros foi dando lugar a professores mais bem orientados e assalariados, incumbidos de modelar os jovens alunos e suas famílias segundo as concepções da nova sociedade que se queria fundar. Dentre outros meios, a revista El Maestro, criada por Vasconcelos e mantida por seus sucessores à frente da SEP, procurou orientar a atuação dos professores e conferir maior unidade e articulação à tarefa de estabelecer a escola laica e gratuita, cumprindo o princípio constitucional fixado em 1917.

Levar a educação ao campo constituiu uma resposta contundente às tensões e aos anseios que vieram à tona nos anos da Revolução, particularmente na zona rural. Como sustentam muitas interpretações sobre o tema, era preciso afirmar a legitimidade do novo Estado perante os diferentes grupos que ajudaram a solapar o regime de Porfirio Díaz e assegurar sua incorporação à ordem política ${ }^{1}$. Ao mesmo tempo, acredito que o envio pelo Estado de professores aos pueblos e municípios rurais representava uma forma de corresponder a uma antiga demanda das populações indígenas e mestiças no México.

Desde o início da colonização, a educação oferecida especialmente pelo clero regular, mesmo que rudimentar, foi vista como uma ferramenta importante para que essas populações defendessem seus direitos ou encontrassem algum caminho de ascensão social. Há uma profusão de documentos indicando a mobilização de pueblos, em diferentes regiões do Vice-Reino da Nova Espanha, em prol da presença de um professor. Mais ainda, de um professor apto a ensinar o catecismo, o espanhol e o alfabeto. Esse tipo de petição ou processo jurídico seguiu sendo recorrente no século XIX.

Por essa razão, ainda que o acesso à escola e às letras estivesse muito distante de se universalizar antes das políticas de massas levadas a cabo a partir da década de 1920, pretendo, neste trabalho, desenvolver a hipótese de que esse foi um horizonte presente para esses grupos sociais em contextos anteriores. Para se ter uma referência, recupero os dados levantados Dorothy Tanck de Estrada a respeito do número de escolas em funcionamento nas comunidades indígenas da Intendencia de México, na região central do Vice-Reino da Nova Espanha, em fins do período colonial: no ano de 1808, contavam com a instituição 457 pueblos, dos 1252 que estavam sob sua jurisdição, reunindo um total de 950 mil índios, em sua maioria de língua náhuatl (TANCK DE ESTRADA, 1996). $\mathrm{O}$ fato de muitas dessas escolas funcionarem já há muitos anos explica que, às vésperas da independência, houvesse núcleos de índios alfabetizados.

Ao mesmo tempo, não é possível deixar de chamar atenção para os casos, mesmo que excepcionais, de indivíduos que encontraram brechas 
para aceder à educação em meio a uma realidade desfavorável. A biografia de Benito Juárez, advogado, futuro presidente da República e protagonista da Reforma Liberal mexicana, representa o percurso emblemático de um índio zapoteco que, muito jovem, fugiu da casa do tio no pueblo de San Pablo Guelatao para buscar instrução na cidade de Oaxaca. Juárez teve a sorte de ser abrigado por Antonio Salanueva, franciscano, encadernador de livros, que lhe conseguiu, entre muitas coisas, um assento como aluno no Colégio Seminário da cidade. A base adquirida nessa instituição permitiu que o estudante passasse a uma carreira laica, como preferia, quando, em 1821, foi aberto em Oaxaca o Instituto de Ciências e Artes (JUÁREZ, 2005) ${ }^{2}$.

Pretendo neste texto, de forma ainda muito preliminar, indicar alguns caminhos por meio dos quais os pueblos indígenas incorporaram usos das letras, frequentemente com ajuda de mediadores letrados - curas, professores, comerciantes, escrivãos, advogados... Serão enfocadas, em particular, experiências localizadas nos estados de Oaxaca e Morelos, respectivamente no sul e no centro do México. Os pueblos desempenharam um papel fundamental na história social, cultural e política de ambos os estados ao longo do século XIX e, como se sabe, durante a Revolução Mexicana.

Vale lembrar nesse sentido, como vêm sublinhando em suas pesquisas Elsie Rockwell, que a apropriação das letras ocorre sempre de forma contextualizada e, portanto, subordinada às práticas culturais específicas de cada grupo. A escola representa apenas um dos agentes - e não o mais importante - que atuam no processo de difusão social das letras (ROCKWELL, 2008).

A perspectiva da autora se contrapõe a linhas de interpretação sobre as relações entre o mundo da oralidade e o mundo da escrita, sustentadas por estudos clássicos como os de Jack Goody a propósito da introdução da escrita em sociedades africanas (GOODY, 1987). Goody concebe a escrita "como meio ligado inerentemente ao pensamento abstrato e descontextualizado", cujo uso "possibilita [...] toda uma série de desenvolvimentos sociais e cognitivos" (ROCKWELL, 1992, p.44). Com efeito, o autor estabelece uma oposição rígida entre as sociedades de tradição oral e as sociedades letradas, sublinhando a tese de que a difusão social do conhecimento letrado conduz à desvalorização do conhecimento transmitido oralmente, o que carrega uma série de implicações sociais e políticas (GOODY, 1987, p. 164). Embora não seja possível ignorar os nexos entre escrita e poder estabelecidos ao longo da História $^{3}$, ficam nítidas na trajetória das populações indígenas, no México do século XIX, as imbricações que se produziram entre a oralidade e a escrita em diferentes esferas do cotidiano das comunidades. 
Este texto pretende enfocar contextos distintos de apropriação e uso das letras por parte das populações indígenas mexicanas. O problema assinalado por Rockwell, de como as tradições e costumes de cada grupo étnico ou linguístico interferem nesses processos, será desenvolvido em uma etapa posterior desta pesquisa. Neste momento, o objetivo central é o mapear contextos em que o recurso às letras foi visto como significativo por determinadas comunidades. Os sentidos conferidos à escrita variaram conforme o contexto.

\section{Usos Indígenas da Escrita na Mesoamérica e na Nova Espanha}

As populações originárias da Mesoamérica têm uma longa história de relações com a escrita que remonta, no período pré-hispânico, aos chamados pictoglifos, produzidos ao longo de mais de dois mil anos. Os escribas-pintores elaboravam o tlacuilolli, para usar o termo em náhuatl, sobre materiais como madeira ou pedra, papel extraído de diferentes fibras naturais ou, ainda, tecidos confeccionados da pele de animais. Os trabalhos consagravam-se a temáticas diversas, dos calendários astronômicos à história do grupo indígena em que tinham origem ${ }^{4}$.

A partir da conquista espanhola, os indígenas entraram em contato com diferentes facetas do universo cultural letrado trazido pelos colonizadores. Os pictoglifos, todavia, continuaram a registrar e a interagir com os movimentos culturais e políticos das populações meso-americanas sob domínio espanhol, como bem demonstram as centenas de códices que chegaram até nós. Parte dos códices coloniais incorporou referenciais técnicos, estéticos e temáticos ocidentais, sem que se apagassem as marcas das estruturas de pensamento indígenas. Paralelamente aos códices, os pictoglifos permearam, de forma mais fragmentada, textos escritos, com propósitos diversos, no alfabeto romano que alguns indígenas começavam a dominar.

No século XVI, as ordens regulares que se transplantaram à Nova Espanha reservaram aos filhos de chefes indígenas uma educação sofisticada - por exemplo, no conhecido Colégio de Tlatelolco, fundado por freis franciscanos em 1536 -, a qual previa o letramento dos alunos. Esse esforço permitiu que integrantes da nobreza nativa desde muito cedo dirigissem cartas ao soberano do trono espanhol, escritas em náhuatl, espanhol ou latim, apresentando solicitações para recuperar seus direitos senhoriais, dentre os quais privilégios nobiliárquicos, a reaquisição de terras pertencentes a ancestrais ou a prerrogativa de cobrar tributos e serviços pessoais de habitantes dos antigos senhorios (PÉREZ-ROCHA; TENA, 2000). Escritas em estilo 
grandiloquente, com referências à história de Roma ou às Sagradas Escrituras, essas cartas revelavam a refinada educação recebida por seus autores e a colaboração de freis espanhois no desenvolvimento da redação.

Ao longo das últimas décadas do século XVI, entretanto, os projetos missionários mais ambiciosos no que concerne à educação indígena perderam ímpeto, arrefecimento que se fez visível também no Colégio de Tlatelolco. Sem me deter no debate sobre as possíveis razões dessa mudança, retomo o balanço realizado por Pilar Gonzalbo Aizpuru em um estudo sobre a educação indígena na época colonial.

Nos tempos da conquista falou-se em 'fazer dos índios homens' antes de fazê-los cristãos; mais tarde se pretendeu transformá-los em melhores cristãos, desterrando as idolatrias e feitiçarias; o objetivo seguinte foi integrálos à vida social da Nova Espanha, e para isso a língua voltava a ser um veículo de assimilação de primeira importância. Na aurora do século XVIII a Nova Espanha aparentava ser uma colônia pacífica, com uma sociedade estável e um futuro sem surpresas ou alterações; a educação dos índios havia passado a ser um problema menor ou nem sequer era considerada como um problema (GONZALBO AIZPURU, 2000).

No que diz respeito aos indígenas sem descendência nobiliárquica, entretanto, a inflexão nas perspectivas educacionais coloniais de fins do século XVI foi menos sentida, uma vez que, desde o início, haviam sido mais tímidas.

Desde 1550, cédulas reais legislaram sobre o ensino do castelhano aos índios. Tratava-se de ensinar a doutrina cristã em espanhol. Estas foram incorporadas na Recompilação das leis de Indias de 1680. Entre 1685 e 1693, o monarca precisou que as caixas das comunidades deveriam fornecer os fundos para os salários dos professores ${ }^{5}$. Acrescentou que se devia ensinar a ler e a escrever em castelhano. Esses princípios foram reiterados durante toda a época colonial.

Esses grupos travaram contato com o universo letrado espanhol, sobretudo por meio da ação de evangelizadores, imbuídos da tarefa de ensinar-lhes espanhol e latim, música, canto litúrgico, teatro catequético e técnicas artesanais. Mas, como sugeriu Gonzalbo Aizpuru, "desde cedo, na Nova Espanha, marcou-se uma diferença entre a vida urbana e a rural, e a educação foi um dos aspectos em que essa diferença se fez mais notável" (STAPLES, 2005, p. 84). A obra educativa concentrou-se inicialmente nos centros mais populosos, retardando o contato da população dispersa pelo campo com os frades.

Em diferentes regiões rurais, a presença missionária ou eclesiástica rarefeita atravessou o período colonial, provocando apreciações desalentadoras 
em diferentes autoridades eclesiásticas que, na Nova Espanha dos séculos XVII e XVIII, avaliavam os avanços da missão catequética e, como dimensão vista por muitos como indissociável da mesma, do ensino do castelhano.

Seja como for, em face dos indígenas "plebeus", os missionários, párocos ou predicadores desempenharam o papel de mediadores entre $o$ texto escrito e sua divulgação oral. Ainda assim, frei Alonso de Molina, autor de El Confesionario Mayor, publicado em náhuatl e em espanhol em 1565, esclarecia no prefácio que a parte mais extensa da obra estava destinada à leitura direta pelos índios (STAPLES, 2005). Em 1599, frei Juan Bautista, um dos muitos vulgarizadores do texto original de Molina, publicou um pequeno Confessionário, também em edição bilíngue, para ser lido pelos confessores, em voz alta, à comunidade reunida.

A despeito das mediações entre escrita e oralidade realizadas pelos evangelizadores, o letramento aos poucos se constituiu em uma demanda dos próprios pueblos indígenas, organização social que, fomentada pela Coroa para proteger os súditos americanos do genocídio, ganhou espaço no Vice Reino a partir de meados do século XVI ${ }^{6}$.

Os arquivos judiciários e administrativos do estado de Oaxaca, para destacar um dos recortes espaciais da pesquisa que desenvolvo, guardam incontáveis pastas com processos relativos às pressões exercidas por comunidades indígenas na passagem da época colonial à independente, em defesa do acesso especialmente das crianças à instrução elementar (STAPLES, 2005). Pois como argumentou Dorothy Tanck de Estrada, existia o costume de se sustentar os professores não com fundos eclesiásticos, mas com dinheiro das caixas das comunidades e dos pais de família. Esta forma de financiamento serviu como base para o estabelecimento de escolas municipais sob o regime da Constituição de Cádiz e no México independente. A transferência dos fundos comunitários aos ayuntamientos constitucionais se cumpriu a partir de 7 de abril de 1821 quando a Diputación Provincial de Nueva España declarou:

Refletindo a Diputación que em muito pueblos onde há ayuntamientos que carecem completamente de arbítrios para responder pelo salário de um professor de escola e que antes do sistema constitucional esse foi satisfeito por conta dos bens da comunidade, acordou que se continue com essa prática (TANCK DE ESTRADA, 1996, p. 45-6).

Em 1809, a Republica del Comum y Natural del Pueblo y Cabezera de San Pablo de Ayutla, distrito de Villa Alta, em Oaxaca, juntamente com um 
pueblo vizinho, dirigiu uma petição ao Vice-Rei reclamando a substituição de um professor encarregado de ensinar a doutrina cristã e a ler, cujo salário onerava a população sem que aquele alcançasse bons resultados com os alunos. A petição vinha assinada por Pasqual Pedro em nome de todos os principales de ambos os pueblos, os quais haviam sido condenados a receber 50 açoites ao apresentarem sua peça inicial ao Subdelegado da Jurisdição de Villa Alta. Diante da resposta do Subdelegado, os signatários esperavam conseguir a intervenção do Vice-Rei, espelhando-se no sucesso de outro pueblo de Villa Alta que, segundo informa a fonte, obtivera seu novo mestreescola (AHJ, 1809).

Em 1811, a Republica del Comum y Natural del Pueblo y Cabezera de San Pablo de Ayutla voltou a dirigir-se à Sua Alteza e à Real Audiência do México para reclamar do professor que lhe fora designado, que além de custar muito para a comunidade, deixava a desejar no preparo dos alunos. O prefeito do pueblo solicitava um novo mestre de primeiras letras, capaz de ensinar a doutrina cristã e a língua de Castela em idioma zapoteco (AHJ, 1811).

As demandas educacionais manifestadas por inúmeras comunidades indígenas de Oaxaca às autoridades coloniais encontraram amparo na legislação adotada pelo Estado Mexicano após a independência, embora, na prática, as dificuldades para um desempenho satisfatório dos maestros persistissem no curso do século XIX.

\section{A Independência e as Perspectivas de Universalização Educacional}

Quando observamos a história da leitura e dos impressos na Europa, projetam-se, como chave para compreendermos o processo de democratização das letras, os discursos e estratégias desenvolvidos por correntes ilustradas e liberais, que conferiam à alfabetização um papel emancipador do povo, ao franquear-lhe o acesso a um repertório cultural considerado válido. No México independente, o letramento também se colocou como horizonte dos projetos de construção nacional, especialmente dos liberais. As leis promulgadas pelo estado de Oaxaca em 1826, assim como as de outras partes do Estado Nacional recém-constituído, previam a universalização da educação.

En cumplimiento de lo dispuesto en el art. 172 de la constitución, y para que los pueblos experimenten beneficios que deben resultarles de una buena administración, el Congreso constituyente ha tenido a bien decretar la siguiente instrucción para el gobierno económico de los Departamentos y pueblos del estado. 
Capítulo I, De las Repúblicas

Art. $1^{\circ}$. Cada república establecerá en su respectivo pueblo una escuela de primeras letras, si ya no estuviera establecida, en la cual se enseñará de balde a los niños pobres a leer, escribir, contar, el catecismo de la doctrina cristiana y el catecismo político: luego que este se haya formado se preferirá el método de enseñanza mutua de dichas escuelas, cuando haya suficientes maestros formados en la escuela normal mandada establecer en la capital de estado. Velará sobre la conducta normal de los maestros, a fin de que puedan dar buen ejemplo a los niños e igualmente acerca del buen desempeño de sus obligaciones y del aprovechamiento de los discípulos. (REINA AOYAMA, 2004, p. 269) ${ }^{7}$.

Entretanto, as diretrizes estabelecidas pela Carta pouco se fizeram sentir na prática. Como sugere o relato do viajante alemão Mühlenpfordt, o cenário educacional de Oaxaca era desolador nos anos que se seguiram à emancipação. Dos 921 pueblos existentes no estado, somente em 395 existiam escolas elementares, "la mayoría miserables en extremo"; delas somente quatro eram sustentadas por fundações beneficentes, enquanto a imensa maioria dependia dos ayuntamientos ou de contribuições voluntárias da população (RUIZ CERVANTES; TRAFFANO, 2006).

A perspectiva é reiterada pelo testemunho do prefeito do Departamento de Villa Alta, sobre o quadro da educação na Sierra Norte no ano de 1837. Embora houvesse na região 83 escolas de primeiras letras assistidas por cinco mil alunos, os resultados eram pífios, pois só ensinavam a

cantar en tonos desagradables la doctrina del Padre Ripalda y a leer la cartilla. Em geral, os professores eram nativos escolhidos entre os habitantes pueblos, entre os "que se creen más aptos o porque han estado al servicio de algún párroco o porque en la capital aprendieron algunas expresiones castellanas (REINA AOYAMA, 2004, p. 269).

Processos como os movidos pelo pueblo de San Pablo de Ayutla, em fins da época colonial, foram recorrentes ao longo de todo o século XIX. As comunidades se queixavam dos custos com que precisavam arcar para manter as atividades de um professor com frequência pouco qualificado. Não se tratava de livrar-se do ônus e abrir mão da demanda, mas de contar com apoio das instituições externas - laicas ou clericais - na montagem de uma estrutura educacional mais eficaz.

Acredito que a noção de eficácia passasse por duas chaves de compre- 
ensão. A educação devia ser eficaz do ponto de vista simbólico, ao permitir a conquista de um horizonte de referências significativo para os habitantes dos pueblos, que promovesse sua inserção em universos sociais, culturais e políticos mais amplos - o catolicismo, o Vice-Reino, logo a nação - percebidos como instâncias simbólicas de afirmação do poder. Devia ser eficaz, por outro lado, do ponto de vista instrumental, como ferramenta de interação com as instâncias de poder, por meio de correspondências, petições jurídicas, leitura de informes etc. É importante sublinhar nesse sentido que os pueblos também fizeram largo uso das letras e dos tribunais de justiça (vice-reinais e mais tarde nacionais) para mediar as tensões internas, entre vecinos e entre comunidades. Nas duas dimensões foi fundamental o papel exercido pelos mediadores.

Contudo, trabalho aqui com a hipótese de que, nas demandas das populações indígenas pelo aprendizado das primeiras letras, prevaleceram os fins instrumentais. Mais do que ingressar em universos sociais, culturais e políticos legitimados pelas elites dirigentes - o que suporia a profunda transformação de seu horizonte de referências -, a familiaridade com as letras visava responder a necessidades prementes de participação, com maior possibilidade de controle sobre os mediadores, em um jogo institucional que essas populações já conheciam e que lhes permitia afirmar certa margem de autonomia ${ }^{8}$.

\section{Usos Jurídicos da Escrita na Nova Espanha e no MÉxico Independente}

Existe uma percepção generalizada, gestada ao longo da Modernidade, de que aqueles que não pertencem à esfera dos homens letrados estão condenados à exclusão social, cultural, política e econômica. Do ponto de vista histórico, sobressai-se a ideia de que aos iletrados estiveram vedadas as possibilidades de participação nos âmbitos institucionais de exercício da política e da pressão social, e que por isso mesmo suas formas de atuação mais marcadas devem ser buscadas no domínio das estratégias cotidianas de resistência, dos motins de rua ou das grandes revoluções.

$\mathrm{Na}$ América Espanhola, entretanto, e aqui me circunscrevo especificamente ao Vice Reino da Nova Espanha, encontramos um quadro muito interessante, fomentado pela Coroa com vistas a proteger seus novos súditos americanos, os quais vinham sendo dizimados desde o início da conquista. Tratou-se de um quadro em que os indígenas, mesmo que na época em sua maioria iletrados, fizeram largo uso mediado da escrita para defender seus interesses em âmbitos institucionais. 
Pois, como é sabido, a Coroa espanhola cedo se preocupou em implementar instâncias jurídicas destinadas a conter os abusos perpetrados pelos colonos em seus domínios na América. Funcionários reais assumiram a tarefa de formalizar, por escrito, a multidão de queixas indígenas encaminhadas à Audiência, aos Tribunais de Província, ao Consejo de Índias ou, a partir de sua instalação em 1592, ao Juzgado General de Indios. Os dois primeiros Vice-Reis da Nova Espanha, Antonio de Mendoza (1535-1550) e Luis de Velasco (1550-1564) empenharam-se em incentivar os indígenas a apresentar-lhes pessoalmente suas denúncias.

Paralelamente, a Coroa e seus representantes no além-mar esforçaram-se para divulgar entre os novos súditos os canais de diálogo abertos. A Real Ordem de 1591, por exemplo, base jurídica para a criação do Juzgado General de Indios, foi proclamada nos pueblos da colônia nas respectivas línguas aborígenes.

Assim, ao longo do século XVI, as populações índias passaram a contar com uma gama de opções para levar adiante, por vias legais, contestações de toda sorte (BORAH, 1996). O estabelecimento dessas instâncias de apelação jurídica estimulou a proliferação de uma prática mobilizadora das comunidades indígenas, prática que se estendeu nas décadas após a independência, no século XIX, sendo as petições a partir daí dirigidas aos tribunais da República.

Tal prática conferia centralidade à escrita e, como é necessário destacar, não apenas à escrita espanhola. Pois os tribunais abertos a litígios envolvendo indígenas também aceitavam como provas manuscritos pictoglíficos. E embora tenham gradualmente abandonado o recurso a testemunhos orais, buscaram simplificar os trâmites processuais a que os indígenas deviam obedecer a fim de atenuar a necessidade de mediação por parte de profissionais do Direito, externos às comunidades.

Ainda que o desejo de respeitar as concepções de justiça próprias do mundo indígena não fosse de todo alheio à Coroa espanhola, as práticas jurídicas espanholas, como conclui Woodrow Borah, acabaram prevalecendo sobre as aborígenes (BORAH, 1996).

A partir de 1592, o Juzgado General de Indios, ativo desde então até o ano de 1820 , passou a atuar como uma espécie de tribunal de primeira instância nos pleitos envolvendo indígenas ${ }^{9}$. As queixas eram em geral escritas por solicitadores em linguagem simples e direta, não especializada. O estilo adotado tornava possível que, em alguns casos, a própria parte redigisse a peça. O mais comum, no entanto, ainda que predominassem as petições escritas em primeira pessoa do singular ou do plural (quando em nome da 
comunidade), era que no final do texto constasse o esclarecimento de que peticionário não sabia ler ou escrever, e por isso não assinava.

A linguagem simples não era exclusiva das petições encaminhadas ao Juzgado General de Indios e, tampouco, do tempo em que a estrutura jurídica vice-reinal ainda buscava consolidar suas formas. Cito como exemplo a petição apresentada em 1801 por Eusébio Jose, Natural y Vecino del Pueblo de Santa Maria Anduayaco, em Oaxaca, a um tribunal eclesiástico, reclamando ser absolvido da prisão a que fora condenado por romper a promessa de casamento que fizera à índia Lorenza Benito, "jusgando que su conducta fuese buena y que fuera doncella" (AHJ, 1801). ${ }^{10} \mathrm{Em}$ seguida, o autor da petição esclarece:

pero haviendo tenido acto carnal con ella, observé que su doncellez era falsa y procuré saver quien havia sido su corruptor. A investigação custou-lhe pouco empenho, já que 'yendo a dar de comer a los Buyes', encontrou-se com um certo Andrés Soriano e ouviu dele a confissão, relatada na peça: "esa es una puta que yo fue el primero que la corrompi (REINA AOYAMA, 2004, p. 269).

Diante da informação, Eusébio Jose argumentou:

[...] y podré yo Señor habiendome cercionado de esto, casarme con esta mujer corrompida, de otro que tiene a la bista [...]? Que matrimonio se me espera? Soy un rustico Indio pero no dejo de reconocer el pesado que sera, y que más servirá para nuestra condenación que para el Servicio de Dios [...]. Su conducta ya la he explicado, su corruptor es ya conocido, que a esta es presiso y natural que le hayan quedado senisas del fuego amorozo que le tuvo, y por cuya fuerza se dejó corromper [...] Que le sucederá al matrimonio que ya conoce y desde el principio el matrimonio no solo imagina, sino que ya ba seloso y desconfiado con la mujer que tiene [...] (REINA AOYAMA, 2004, p. 269).

As justificativas assim se seguem, reiterando ao juiz sua determinação em não se casar com Lorenza e sugerindo que a pena de prisão se realizasse contra o corruptor da moça.

Assim como a simplificação das formalidades linguísticas, a Coroa esforçou-se para suavizar a cobrança das taxas que encareciam os processos. Enfrentou, todavia, permanente resistência dos profissionais espanhois de justiça ávidos por lucrar com o recurso das partes à mediação jurídica. 
Não raro, o dinheiro recolhido para arcar com os impostos envolvidos nos processos acabava embolsado pelos solicitadores. Da mesma forma, funcionários reais pagos para auxiliar os indígenas nas moções - agentes de índios, intérpretes, relatores e escrivãos - cobravam soldo complementar de seus representados. A Coroa reagia a essas práticas com novas regulamentações e com o estabelecimento de novas instâncias mediação, graciosamente disponibilizadas aos indígenas. Ao longo da segunda metade do século XVI, proibiu os intérpretes de ajudar as populações locais a produzir documentos ou manuscritos pictóricos e criou as figuras do assalariado defensor dos índios, do letrado assalariado e do gestor.

As iniciativas não foram capazes de por fim ao ônus financeiro que o recurso à justiça representava, mas certamente contribuíram para que os indígenas reconhecessem os tribunais vice-reinais como instâncias que estavam abertas para escutar e, por vezes, acolher suas queixas.

A emancipação política mexicana significou o fim das instâncias jurídicas protetoras dos índios. José Maria Luis Mora, um dos porta-vozes do projeto liberal para a construção nacional, considerava que

el indio era una persona atrasada debido al tutelaje al que estuvo sometido en la Colonia y consideró fundamental la idea de la propiedad privada que permitiría el desarrollo del país así como la incorporación de los indígenas a una sociedad con unas mismas leyes y derechos civiles y políticos. (RUIZ CERVANTES; TRAFFANO, 2006, p. 197) ${ }^{11}$.

Nos anos 1850 e 1860, como é sabido, os liberais se empenhariam em suprimir as comunidades indígenas como corporações juridicamente reconhecidas. A despeito do desaparecimento dos tribunais especiais, nos anos que se seguiram à independência, os indígenas continuaram recorrendo aos tribunais da República, individualmente ou em nome do pueblo, em defesa de suas terras, para contestar impostos, em disputas por heranças, para queixar-se dos alcaldes ou da Igreja, entre outras razões. Também aqui nos deparamos com o trabalho de mediadores - advogados, escrivãos da República, assistentes... -, que deram forma escrita aos casos apresentados por indígenas à Justiça ${ }^{12}$.

Usualmente, mesmo que escrita em $1^{\text {a }}$. pessoa ou em nome do pueblo, a petição trazia a assinatura de um assistente ou um advogado. Observemos, por exemplo, um processo, de 1829, apresentado ao Juzgado de Ialalog pela República, Comum y Naturales del Pueblo de Santa Maria Yoviche reclamando terras fronteiriças invadidas pelo pueblo vizinho, Yagallo, que lhe 
pertencia por título. A petição era assinada por um alcalde, um assistente e um advogado.

Embora produzida com mediação externa à comunidade, esta peça, como muitas outras apresentadas por pueblos de Oaxaca, expressava o diálogo com o universo cultural indígena ao, por exemplo, empregar termos em idioma aborígine para designar lugares ou marcos fronteiriços. A petição sustentava,

que el dia veinte y ocho del pasado Abril la Republica del pueblo nuestro colidante de Santiago Yagayo se introdujo em las tierras de nuestra pertenencia e y paraje nombrado en el idioma del país Lachiroayeya: de cuyo exceso dimos parte imediatamente a la autoridad de $V^{\circ} y$ en consecuencia se sirvio librar una orden para que los de Yagayo se contuvieron en sus limites y desistieran de la atentada introducción, conservando la tranquilidad y buena armonia con sus vecinos. Recibida y conducida dicha [ilegível], la manifestamos al Alcalde $1^{\circ}$. de Iagayo, quien lejos de obedecer su precepto y reprimir la audacia de sus subditos, fue junto con ellos el cinco de dicho mes a auyentar a los de nuestro pueblo que estaban rosando sus tierras; y el dia siguiente seis del mismo mes, quitaron la cruz que servia de lindero divisorio en el paraje llamado en el idioma Iegotec chichibechi [...] (AHJ, 1829) ${ }^{13}$.

Por outro lado, os mediadores a serviço da República, contratados pelas comunidades ou integrantes das mesmas incumbiram-se de organizar e revestir as queixas indígenas de certas formalidades próprias da linguagem jurídica.

Em um processo civil de 1849, do estado de Oaxaca,

los ciudadanos Narciso Garcia y Nicolas Alejandro, Alcaldes, Francisco Antonio Miguel y Miguel Pedro, Regidores, asi como Juan Pablo Manuel escrivano de la municipalidad del pueblo de San Pedro Cajanos, por si y a nombre de los demas vecinos de dicho pueblo, por si y a nombre de los demas vecinos de dicho pueblo, por quienes prestamos caucion [...] (AHJ, 1849).

Formularam uma contestação ao "Señor Juez de primera Instancia”, argumentando serem verdadeiros e de "buena fé" os testemunhos que haviam reunido na petição inicial, acusando o pueblo vizinho, San Francisco Cajanos, de haver despojado terrenos seus. Os fundamentos e objetivos da 
contestação são apresentados em linguagem simples e objetiva.

Protestando como desde luego protestamos no perder nuestros terrenos, tanto porque son nuestra legitima propiedad, cuanto porque ellos solos son los que proporcionan a nuestro pueblo la necesaria subsistencia, pues aunque posemos otros son montanosos y de muy poco provecho (AHJ, 1849).

Os autores da queixa argumentavam que poderiam ter fornecido à justiça desde o início informação mais ampla, mas que se abstiveram de fazê-lo por acreditarem que um reconhecimento "ocular" dos terrenos seria suficiente para esclarecer os direitos de cada uma das partes e que, com isso, não se daria lugar "para que la malicia entrara en ejercisio (sic)". Por isso, solicitavam ao juiz anexar ao processo títulos que os favoreciam, para que servissem de prueba, conforme expresso no documento.

Além dos cuidados procedimentais, a peça obedecia a uma estrutura textual e a determinadas fórmulas de linguagem que se repetiam, com pequenas variações, nos diferentes processos que analisei. Assim, por exemplo, a petição finalizava com a súplica dirigida ao juiz para que "se sirva prover en todo como pedimos". Juan Pablo Manuel, o escrivão citado como co-autor da petição, assina "por los Alcaldes y regidores que no saben firmar" (AHJ, 1849).

\section{Professores de Primeiras Letras em Anenecuilco, Estado de Morelos}

Nas últimas décadas do século XIX, encerrada a guerra civil que consolidou a vitória dos liberais sobre os conservadores mexicanos, o Estado passou a ocupar um lugar proeminente na educação. Durante o Porfiriato (1876-1911), o governo viria a cercar-se de um seleto grupo de intelectuais positivistas - os chamados Científicos -, incumbido de traçar o caminho do progresso nacional e de legitimar as políticas oficiais. A Gabino Barreda caberia a organização da educação nacional. Tratava-se de estruturar um ensino homogêneo e centralizado para todo o país. Sua maior realização foi no âmbito da educação secundária, com a criação da Escola Nacional Preparatória, que formaria quadros para as carreiras profissionais e contribuiria "para cimentar o único meio de conciliar a liberdade com a concórdia e o progresso com a ordem” (ZEA, 1980, p. 17). A educação primária, porém, continuaria a cargo dos estados, que se confrontavam com o desafio de tornar a escolarização obrigatória a crianças em boa medida de meios rurais e indígenas (BAZANT, 1999).

Já no ano de 1872, o governador de Morelos, Francisco Leyva, decretou a obrigatoriedade da educação em todo estado. Naquele mesmo ano, os pue- 
blos vizinhos de San Miguel de Anenecuilco e de Villa de Ayala organizaramse para contratar um preceptor que levasse adiante a tarefa antes assumida por moradores locais, Pedro Zapata e, em seguida, Francisco Zapata.

Don Mónico Ayala, filho de Francisco Ayala, "professor que marcara a vida de muitos dos que o escutaram", colocou-se à frente de uma escola bem montada - três portas arejavam a sala de aula, onde mais de 20 crianças distribuíam-se em sete bancos. Para os estudos, os alunos dispunham de uma mesa grande, lousas, compêndios de história do México, um livro de aritmética para cada criança e os silabários de San Vicente (HERNÁNDEZ CHÁVEZ, 1991) ${ }^{14}$.

De acordo com Alicia Hernández Chávez,

Os homens de 1911, que eram crianças em 1879, lembravam que o maestro guardava nas gavetas da meda grande um exemplar da cartilha lancasteriana e outro exemplar do orçamento geral do estado, além das listas de assistência e outras anotações. Seu professor lhes ensinou a história do México, que era do que todos mais gostavam. Junto com a história de seus herois lhes falou das novas Constituições por que haviam lutado seus pais, e todos aprenderam aritmética, moral e gramática. $\mathrm{Na}$ escola se discutia muitíssimo. Seu preceptor lhes dizia com orgulho que ele ensinava com o sistema lancasteriano, que segundo lhes explicou consistia em que todos participassem ativamente e discutissem as afirmações do professor. A essa escola assistiam 19 meninos e três meninas, alguns de Ayala e outros de Anenecuilco, o que era pouco usual, pois em geral separavam-se os meninos das meninas, ou simplesmente nem se enviavam as meninas.

Entre os alunos de Don Mónico estiveram Eufemio Zapata, de 12 anos, e dois de seus irmãos. Don Mónico durou vários em seu posto, e entregou a escola a seu sucessor em 1879, não sem deixar profundamente arraigado o exercício da participação e da discussão em temas tão diversos como as leis, a história, os números e a escrita (AHJ, 1849) ${ }^{15}$.

Se é possível aceitar a hipótese de que a experiência da geração que mais tarde responderia ao chamado de Francisco Madero contra Porfirio Díaz e, um ano mais tarde, em novembro de 1911, abraçaria a Plano de Ayala de Emiliano Zapata, foi marcada pela experiência compartilhada na escola de don Mónico, é preciso iluminar também o papel desempenhado já no contexto da Revolução pelo professor de primeiras letras Otilio Montaño. 
Natural de Villa de Ayala, frequentou a escola primária Guillermo Prieto, na cidade de Cuautla, poucos quilômetros ao norte de seu pueblo. Ao concluí-la, tornou-se professor da escola de Tepalcingo e em seguida de Jonacatepec. Retornou então à Villa de Ayala, na condição de diretor da escola. Era uma figura conhecida e prestigiada no pueblo, sempre disposto a professar suas ideias nas convivências da praça central.

Algum tempo mais tarde, foi promovido à escola de Yautepec. Em março de 1911, estava de volta à Villa de Ayala, desta vez para conclamar a população a aderir à Revolução. Nos meses seguintes, se tornaria um colaborador próximo de Emiliano Zapata. Quando o general decidiu recusar a paz proposta por Francisco Madero e lutar pelas demandas dos pueblos do centro e do sul do México, coube a Otilio Montaño, acredita-se, dar forma escrita aos argumentos que compuseram o Plano de Ayala.

Quando em 1914, após a derrocada de Victoriano Huerta, instaurou-se o governo da Convenção Revolucionária de Aguascalientes, o professor assumiu o posto de Ministro da Instrução Pública. Como a guerra prosseguiu, todavia, não houve tempo para políticas arrojadas. Em 1917, Montaño encerrou a vida executado por ordem de Zapata, a quem foi acusado de trair.

Já foi sublinhado por diferentes historiadores o papel desempenhado por intelectuais que, no curso da Revolução Mexicana, se aproximaram dos movimentos de origem popular, imprimindo neles suas próprias marcas ideológicas. Não é essa a discussão que interessa a este trabalho.

Parece-me sim fértil pensar que professores de primeiras letras como Mónico Ayala e Otilio Montaño representaram mais um canal por meio dos quais os pueblos indígenas travaram contato com a escrita e a leitura e incorporam usos que lhes pareceram estratégicos em contextos específicos. Desta vez, reforçar os princípios do comunitarismo indígena e conferir publicidade e autoridade a um documento que definia o lugar desses grupos no contexto da Revolução. Afinal, podemos observar na trajetória do Plano de Ayala - segundo a versão oficial zapatista, dentre as muitas que já se produziram - as imbricadas relações entre leitura e escrita.

Segundo esta versão, Zapata se incomodou porque os jornais da capital haviam dito que suas incursões do mês de outubro em Morelos e no Distrito Federal tiveram como único objetivo o saque. E pediu a Montaño que traçasse um programa para demonstrar que os zapatistas não eram simples bandidos. Aconselhados pelos chefes principais, Montaño e seus assistentes redigiram uma versão provisória. Em princípios de novembro, Zapata a examinou e a elogiou, mas considerou que já não era necessária por causa do pacto que ia estabelecer com Robles Domínguez. Quando as negociações fracassaram, 
Zapata e Montaño fugiram para as montanhas de Puebla. Ali redigiram a versão final. As ideias eram as que segundo Zapata constituíam consenso entre seus chefes; a expressão formal foi, sobretudo, de Montaño. Quando o terminaram, Zapata reuniu todos os chefes da zona, e em um pequeno povoado próximo de Ayoxustla leu o Plano para que assinassem. Zapata depois transferiu-se para o quartel general nas montanhas de Morelos, nas proximidades de Huautla, onde um sacerdote copiou à máquina vários exemplares do Plano. Zapata os enviou às embaixadas da cidade do México e a seu agente principal na capital, Gildardo Magaña. Disse a esse último que suspendesse as conversações com o maderismo e que tratasse de publicar o 'importante documento'. De todos os editores metropolitanos, só Bonilla, do Diario del Hogar, perguntou a Madero se podia publicá-lo. 'Sim - disse Madero - publique para que todos conheçam esse louco Zapata'. E assim o fez, em 15 de dezembro, em uma edição dobrada que rapidamente se esgotou (WOMACK JR., 1997).

O Plano trazia as marcas semânticas (reforma, justiça, lei, liberdade...) de outros documentos revolucionários e, em particular, do jornal liberal Regeneración, que Zapata e Montaño conheciam e que os correios lhes fazia chegar da capital. Os caminhos de elaboração e de divulgação do Plano de Ayala sugerem uma reflexão sobre usos que articulavam o universo da oralidade e ao universo da escrita, buscando responder a finalidades específicas de comunicação. Se os chefes indígenas escutaram a leitura do plano, respeitando a tradição das assembleias que deliberavam sobre assuntos dos pueblos, sua assinatura formalizaria a aceitação do documento. Ao mesmo tempo, a publicação em um jornal da capital levaria a mensagem de Zapata e seus comandados aos heterogêneos interlocutores de todo o país, que não estavam ao alcance da palavra falada.

O trânsito entre a oralidade e a escrita constituiu, ao longo de séculos, um caminho importante para que as populações indígenas interagissem com as dinâmicas sociais e políticas introduzidas pelas novas elites, coloniais e nacionais. Os professores primários, ao lado de outros mediadores, foram figuras chave no processo de aproximar repertórios culturais letrados e a produção de textos escritos aos usos significativos para a afirmação dos pueblos e de seus habitantes em meio às teias de poder e de tensões sociais em que estavam envolvidos. Não por acaso, os maestros de primeras letras também marcaram seu lugar na cena em que os camponeses irromperam na Revolução.

Literacy and Cultural Mediation in Indigeneous Communities of Center South MÉXICO IN THE $19^{\text {TH }}$ CENTURY 
AвstRACT: This article aims at shedding light on the uses of reading and writing inherited and applied by the indigenous communities in the state of Oaxaca in Mexico after the independence. Since the colonial era, writing represented an important instrument for the communities to address the vice-royal tribunals in defense of their lands and rights. The writing of legal petitions was carried out by literate mediators, who wrote down the oral testimonies. With the independence of New Spain, in 1821, this tradition persisted, although adapted to the juridical structure of the new born National State. On the other hand, throughout the 19th century, many communities kept making efforts in order to assure the presence of an elementary teacher capable of promoting literacy and fluency in Spanish among the new generations.

KEYwords: Mexico, 19th century, indigenous, literacy, education

NoTAS

1 Ver, por exemplo, Vaughan (2001); Palacios (1999); Crespo (2004); Loyo (2003).

2 Vale aqui lembrar o argumento apresentado por Lawrence Stone em um artigo intitulado Literacy and Education in England: 1640-1900, de que, na Inglaterra desse período, a estratificação social era quem definia a estrutura educativa, uma vez que cada nível de educação formal era orientado segundo as necessidades específicas de cada camada da sociedade, com o claro propósito de reforçar as distinções de classe e de reduzir a mobilidade social. Stone coloca que a educação dada às crianças de cada grupo em geral correspondia aos requisitos da posição social que herdariam no futuro. A brecha que o autor identifica na rigidez deste sistema é o que ele chama de sponsered mobility, que permitia a uns poucos talentosos, por meio de uma bolsa de estudos, ultrapassar os limites impostos ao seu grupo. (STONE, 1969, p. 73). É certo que Benito Juárez não contou com uma bolsa de estudos, mas que seus méritos intelectuais o ajudaram a percorrer níveis educacionais dominados por representantes das elites criollas.

3 Ver, no que diz respeito à América Latina, Rama (1985).

4 Um balanço do estado atual das discussões sobre a natureza dessa fonte estão em Santos (2005).

5 Sobre os gastos das comunidades indígenas com educação, ver Staples (2005).

6 Sobre o processo de formação dos pueblos indígenas no período colonial ver Lockhart (1998, p. 98-119).

7 Neste artigo, optei por não traduzir as fontes primárias para o português. 
8 Sobre as relações entre o aprendizado, a leitura e os repertórios culturais mobilizados pelo leitor, ver a obra de Lahire (1997). Sobre as estreitas relações entre o processo de letramento e a transformação do horizonte de referências do indivíduo ver Hébrard (1996, p. 35-74).

9 O funcionamento judiciário do Juzgado General de Indios chegou ao fim quando as disposições da Constituição espanhola de 1812 foram novamente implantadas no México, em 1820. A Constituição de Cádiz transformava os índios em cidadão plenos e, nesse sentido, suspendia a necessidade de tribunais especiais.

10 Esclareço que, nas citações de fontes primárias ao longo deste artigo, mantive a ortografia presente nos documentos.

11 Para uma análise do pensamento de José Maria Luis Mora, ver também Prado (1999).

12 Ocasionalmente, nos processos dos Fondos Civis de Teposcolula e de Villa Alta reunidos no Archivo Histórico Judicial, em Oaxaca, a petição era assinada unicamente pelo queixoso, sem a presença explícita de mediadores. Exemplo: Foi esse $o$ caso de um processo movido por índios mixtecos de uma mesma família, em 1825, reclamando que se encaminhassem ao alcalde do pueblo e ao cura a restituição das terras legadas por seus avós e tomadas pelos Mayordomos de la Cofradía Nuestra Señora de Guadalupe. Um dos membros da família, Mariano Figueroa, assinou a petição pelos demais (AHJ, 1825).

13 Processo de 1829 apresentado ao tribunal judiciário de Ialalog pela Republica, Comum y Naturales del Pueblo de Santa Maria Yoviche, reclamando terras fronteiriças invadidas pelo pueblo vizinho, Yagallo.

14 Lembro que o sistema lancasteriano foi proposto, na Inglaterra, por Joseph Lancaster (1778-1838), visando à educação dos filhos de trabalhadores. O método teve extraordinária repercussão em diferentes partes da América Espanhola.

15 Sobre esse tema, ver também Sotelo Inclàn (1943)

\section{REFERÊNCIAS}

AHJ. Archivo Histórico Judicial, Oaxaca. Fondo Teposcolula, Serie Civil, Legajo 0060, Exp. 0043, 1825.

AHJ. Archivo Historico Judicial, Oaxaca, Fondo Villa Alta, Serie Civil, Legajo 0038, EXP. 0014, 1809.

AHJ. México, Oaxaca, Archivo Historico Judicial, Fondo Villa Alta, Serie Civil, Legajo 0039, EXP. 001, 1811.

AHJ. México, Oaxaca, Archivo Historico Judicial, Fondo Teposcolula, Serie Civil, Legajo 0053, 0030, 1801. 
AHJ. México, Oaxaca, Archivo Historico Judicial, Fondo Villa Alta, Serie Civil, Legajo 0045, EXP. 0009, 1829.

AHJ. Archivo Historico Judicial, Oaxaca, Fondo Villa Alta, Serie Civil, Legajo 0049, EXP. 0016, 1849

BAILEY, David. Revisionism and the recent historiography of the Mexican Revolution. Hispanic American Historical Review (Duke University Press), v. 58, n. 1 (Feb. 1978), p. 62-79.

BAZANT, Mílada. Historia de la educación durante el Porfiriato. México: El Colegio de México, 1993.

. La disyuntiva entre la escula y la cosecha : entre las multas y los arrestos.

El Estado de México de 1874 a 1910. In: GONZALBO AIZPURU, Pilar (Coord.). Familia y educación en Iberoamérica. México: El Colegio de México, Centro de Estudios Históricos, 1999.

BONFIL BATALLA, Guillermo. México profundo. México: SEP, 1987.

BORAH, Woodrow. El Juzgado General de Indios en la Nueva España. México: FCE, 1996.

CASTAÑEDA GARCIA, Carmen; GALVAN LAFARGA, Luz Elena; MARTINEZ MONCTEZUMA, Lucia (Coords.). Lecturas y lectores en la história de México. México, Ciesas, El Colegio de Michoacan, Universidad Autonoma del Estado de Morelos, 2004.

CASTAÑEDA GUZMÁN, Luis (comp.). Cordilleras eclesiásticas de Oaxaca: 18201880. Oaxaca: Centro Regional de Oaxaca: INAH, 2002.

CHARTIER, Roger (Org.). Práticas da leitura. São Paulo: Estação Liberdade, 1996.

COOPER-RICHET, Diana; MOLLIER, Jean-Yves; SILEM, A. (Dirs.). Passeurs culturels dans le monde des médias et de l'édition en Europe (XIXe et XXe siècle). Villeurbanne, Presses de l'enssib, 2005.

CRESPO, Regina. Itinerarios intelectuales: Vasconcelos, Lobato y sus proyectos para la nación. México: UNAM, 2004.

DALTON, Margarita (Comp.). Oaxaca: textos de su historia. México: Instituto Mora, 1997. V. II, III.

. Oaxaca: una historia compartida. México: Instituto Mora, 1997.

ESPAGNE, Michel. Sur les limites du comparatisme en histoire culturelle. Genèses, Paris, n.17, set. 1994.

GONZALBO AIZPURU, Pilar. Historia de la educación en la época colonial. El mundo indígena. México: El Colegio de México, 2000. 
GONZALBO AIZPURU, Pilar (Coord.). Educación rural e indígena en Iberoamérica. México: Colegio de México: Universidad Nacional de Educación a Distancia, 1996. GOODY, Jack. The interface between the written and the oral. Cambridge: Cambridge University Press, 1987.

HÉBRARD, Jean. O autodidatismo exemplar: como Valentin Jamery-Durval aprendeu a ler? In: CHARTIER, Roger (Org.). Práticas da leitura. São Paulo: Estação Liberdade, 1996. p. 35-74.

HERNÁNDEZ CHÁVEZ, Alicia. Anenecuilco: memoria y vida de un pueblo. México: Colegio de México, 1991.

JUÁREZ, Benito. Apuntes para mis hijos. Tabasco: Universidad Juárez Autónoma de Tabasco, 2005.

KATZ, Friedrich. Revuelta, rebelión y revolución: la lucha rural en México del siglo XVI al siglo XX. México: Era, 1990.

KOBAYASHI, José María. La educación como conquista. México: El Colegio de Mexico, 1997.

LAHIRE, Bernard. O sucesso escolar nos meios populares: as razões do improbable. São Paulo: Ática, 1997.

LEÓN-PORTILLA, Miguel. El destino de la palabra: de la oralidad y los códices mesoamericanos a la escritura alfabética. México: El Colegio de México; Fondo e Cultura Económico, 2000.

LOCKHART, James. Of things of the Indies: essays old and new in early Latin American History. California, Stanford University Press, 1998.

LOYO, Engracia. Gobiernos revolucionários y educación popular en México, 19111928. México, Colegio de México, 2003.

PALACIOS, Guillermo. La pluma y el arado: los intelectuales pedagogos y la construcción sociocultural del problema campesino en México, 1932-1934. México: El Colegio de México, 1999.

PÉREZ-ROCHA, Emma; TENA, Rafael. La nobleza indígena del centro de México. Córdoba: Instituto Nacional de Antropología e Historia, 2000.

PRADO, Maria Lígia Coelho. América Latina no século XIX: tramas, telas e textos. São Paulo: Edusp, 1999.

RAMA, Ángel. A cidade das letras. São Paulo: Brasiliense, 1985.

REINA AOYAMA, Leticia. Historia de los pueblos indígenas de México. México: CIESAS; CDI, 2004.

ROCKWELL, Elsie. Hacer escuela, hacer estado. La educación posrevolucionaria vista desde Tlaxcala. Michoacán, El Colegio de Michoacán; CIESAS; CINVESTAV, 2007. 
. Los usos magisteriales de la lengua escrita. Revista Nueva Antropología, México, n. 42, v. XII, p. 43-55, jul. 1992.

. Relaciones com la cultura escrita en una comunidad nahua a princípios del siglo XX: temas recurrentes en los relatos orales. Revista Lingua Escrita (revista digital do CEALE/FAE/UFMG), IV, 2008.

RUIZ CERVANTES, Francisco José e TRAFFANO, Daniela. "Porque solo la ilustración puede desterrar de esos pueblos los vicios y la inmoralidad que los dominan". Indígenas y educación en Oaxaca, 1823-1867. Revista de História (Depto. de História/ USP), n. ${ }^{\circ} 154,1 .^{\circ}$ semestre de 2006. Dossiê História dos Índios.

SANTOS, Eduardo Natalino dos. Usos historiográficos dos códices mixteconahuas. Revista de História (Depto. de História/ USP), n. ${ }^{\circ} 153,2 .^{\circ}$ semestre de 2005. Dossiê História das Américas.

STAPLES, Anne. Recuento de una batalla inconclusa: la educación mexicana de Iturbide a Juárez. México: El Colegio de México, 2005.

SOTELO INCLÀN, Jesús. La Escuela de Anenecuilco. Cuernavaca, Morelos, Cuadernos Zapatistas, 1979.

. Raíz y razón de Zapata. Investigación histórica, México, 1943.

STONE, Lawrence. Literacy and education in England: 1640-1900. Past and Present, n. 42, 1969. SUÁREZ DE LA TORRE, Laura. (Org.) Constructores de un cambio cultural: impresores-editores y libreros en la ciudad de México, 1830-1855. México, Instituto Mora, 2003.

TANCK DE ESTRADA, Dorothy. Escuelas en los pueblos de índios de la Intendencia de México en 1808, según los reglamentos de los bienes de comunidad. In. GONZALBO AIZPURU, Pilar (Coord.). Educación rural e indígena en Iberoamérica. México: Colegio de México; Universidad Nacional de Educación a Distancia, 1996.

VAUGHAN, Mary Kay. La política cultural en la Revolución: maestros, campesinos y escuelas en México, 1930-1940. México: FCE, 2001.

VILLORO, Luis. Los grandes momentos del indigenismo en México. México: CIESAS: SEP, 1987.

WARMAN, Arturo. Los indios mexicanos en el umbral del milenio. México: FCE, 2003.

WOMACK Jr., John. Zapata y la Revolución Mexicana. México: Siglo XXI, 1997. 